Review

\title{
Implementing Continuous Cover Forestry in Planted Forests: Experience with Sitka Spruce (Picea Sitchensis) in the British Isles
}

\author{
William L. Mason \\ Forest Research, Northern Research Station, Roslin, Midlothian EH25-9SY, UK; \\ E-Mail: bill.mason@forestry.gsi.gov.uk; Tel.: + 44-0300-0675-955; Fax: +44-0131-4455-124 \\ Academic Editor: Eric J. Jokela
}

Received: 15 January 2015 / Accepted: 9 March 2015 / Published: 24 March 2015

\begin{abstract}
Planted forests of Sitka spruce, a non-native species from north-west America, are the major forest type in Great Britain and Ireland. Standard management involves even-aged stands, rotations of 40-50 years and a patch clear-felling system with artificial regeneration. However, forest policies support managing these forests for multifunctional objectives with increased diversity of species composition and stand structure. Continuous cover forestry (CCF) is an alternative silvicultural approach used to provide such diversity, but the amount of CCF forest is under $10 \%$ of the forest area, and less in Sitka spruce forests; This paper reviews research carried out in the last two decades to support the implementation of CCF in Sitka spruce planted forests; Stand structures and microclimate favouring natural regeneration are understood. Harvesting systems have been adapted for use in CCF stands, a single-tree growth model has been calibrated, comparative costs and revenues have been determined, and operational trials established. The interaction between thinning and wind stability in irregular stands is problematic, together with the lack of suitable species for growing in mixture with Sitka spruce; Introduction of an alternative silvicultural approach may take decades and must overcome technical challenges and cultural resistance.
\end{abstract}

Keywords: Planted forests; Sitka spruce; transformation; continuous cover forestry

\section{Introduction}

A major land-use change in the British Isles in the previous century was the expansion of the forest area through the establishment of extensive planted forests of non-native conifers in the upland 
zones of both Britain and Ireland [1,2]. The main silvicultural system applied in these forests was patch clear-felling combined with artificial regeneration [3]. There were some early critics of this simple silvicultural regime who called for more species diversification in planted conifer forests and for the use of silvicultural systems that provided greater variation in stand structure [4-7]. Nevertheless, for many years the practical impact of such criticisms was limited because the main focus of forestry activity, and of underpinning research, was to support the extensive afforestation programmes in both Britain and Ireland. These programmes had the aims of increasing the amount of forest cover and of producing usable timber at a reasonable rate of return [8].

During the last two decades of the twentieth century there was increasing awareness of the importance of other types of ecosystem service provided by forests such as landscape, recreation and biodiversity [2]. There was recognition that meeting these multi-functional objectives in planted forests would require a move away from the simple structures and single species stands characteristic of patch clear-felling regimes towards more irregular forests composed of a range of tree sizes and of a mixture of species [9]. Such varied structures are considered to be beneficial for biodiversity [10] and to be preferred by visitors [11]. The development of irregular forests with mixed species composition is also proposed as one way of adapting British forests to projected climate change $[12,13]$. Therefore, the implementation of more complex and diversified forests is now explicitly supported in forest policy documents in various countries of the British Isles such as Ireland, Scotland and Wales [14-16]. One means of achieving this change is through increased adoption of Continuous Cover Forestry (CCF), an approach to forest management which seeks to manage the forest ecosystem rather than purely the trees, which uses natural processes as the basis of stand management, which works with site limitations, and which seeks to create diverse stand structures with a range of species $[17,18]$. The approach is implemented by silvicultural systems which avoid the use of clear-felling and thus maintain a continuity of woodland conditions across the site (hence "continuous cover").

Although Malcolm et al. [9] estimated that up to half the area of conifer planted forest in Britain could be suitable for transformation to CCF based on knowledge of soils and wind climate, they believed that perhaps only $5 \%$ of these forests were being managed using this approach. Despite the ongoing support for $\mathrm{CCF}$ in country policy documents, precise figures on the areas that have been placed under this type of management are difficult to obtain. A recent review of the adoption of CCF in British forestry identified some 60 thousand ha of woodlands actively managed under this approach (around 3\% of forest cover) [19]. However, this review also noted a much larger area in public forests where there were aspirations to transform forests to irregular structures in the near future: the area involved amounted to around $20 \%$ of public forests in Great Britain [19, unpublished data]. In the Irish republic, Vitkova et al. [20] found just over 10 thousand ha being managed under CCF (less than $2 \%$ of the forest area) and much of this had only been designated in the last 15 years. Examination of these reviews suggests that adoption of CCF has tended to be concentrated in mixed woodlands in more sheltered regions as well as in broadleaved woodlands in public forests in Ireland. By contrast, there are relatively few examples of CCF being implemented in the single species conifer plantations established in the last century in upland Britain, and in particular in the extensive forests dominated by Sitka spruce (Picea sitchensis (Bong.) Carr.).

Sitka spruce was introduced into the British Isles in 1831 from north-west America by David Douglas [21]. In its natural range the species is mainly confined to coastal forests between Alaska and northern California where individual trees reach the largest dimensions recorded for any member of the 
genus Picea [22]. David Douglas had identified the species' ability to grow to large sizes on nutrient poor shallow soils as a valuable feature for British conditions [23]. The first major imports of seed into Britain were in 1852 and the rapid growth of specimen trees in arboreta led to the establishment of trial plantations in Scotland from 1882 [24]. The good results from these trials, as well as from those in Ireland [1], resulted in this non-native spruce becoming the main species used in afforestation in the British Isles from 1950 onwards. Thus in Britain the proportion of Sitka spruce rose from 11\% of all conifers planted in the 1920s to nearly $70 \%$ in the 1980s [3]. Forests of Sitka spruce are now the major forest type in both Great Britain and Ireland, covering more than 1 million ha, and there are also substantial areas planted with this species in oceanic regions of mainland Europe such as Brittany, Denmark and Norway [25].

From the early days of its introduction into British forestry, the practice was to grow Sitka spruce in pure even-aged stands managed on comparatively short rotations (40-60 years) for the production of small roundwood and sawlogs [24-26]. The oceanic climate of upland areas of the British Isles can result in serious risks of wind damage to these spruce stands, particularly when located on exposed sites with moist soils resulting in shallow rooting. As a result, many Sitka spruce forests have been managed either on non-thin regimes or with very limited thinning because of the risks of windthrow [27]. Small proportions of other conifer or broadleaved species may be planted in forests dominated by Sitka spruce, but these would be deployed in discrete stands primarily for aesthetic or biodiversity reasons [28]. The main exception to the use of spruce in pure stands was where the species was planted in "nursing mixtures" on nutrient poor soils, particularly in the presence of ericaceous vegetation (e.g., heather-Calluna vulgaris L. Hull) when it was admixed with species such as Scots pine (Pinus sylvestris L.), lodgepole pine (Pinus contorta Dougl.) or Japanese larch (Larix kaempferi Lamb. Carr.) [29,30]. At the end of the rotation, the stands are clear-felled with a coupe size varying from 5 to 30 ha depending upon the visibility of the site and the shape of the landform [28]. Felling is generally followed by planting with a target stocking density at establishment of around 2500 stems ha $^{-1}$ [25]. Thus conventional management of Sitka spruce forests would conform to an international typology of intensive tree plantations [31].

Natural regeneration of Sitka spruce has been observed in British forests since the early 1950s [32,33], and stocking densities in excess of 10,000 naturally regenerated stems ha ${ }^{-1}$ have been reported [34-37]. Such regeneration has mostly been managed through respacing (pre-commercial thinning) to develop even-aged stands of regular spacing [37]. However, there was also recognition that the occurrence of natural regeneration offered the possibility to increase the structural and species diversity in planted forests. One of the six experimental areas initiated by Edinburgh University in the 1950s to examine the transformation of even-aged stands [38] was located on the Corrour estate in northern Scotland in stands where Sitka spruce regeneration had been noticed in windblown gaps [39]. Penistan [40] recommended the use of groups of $0.1-0.4$ ha for the restocking of spruce forests, accompanied by enrichment planting to increase species diversity. Studies of the effect of different gap sizes on the stability of the surrounding edge trees indicated a greater incidence of windthrow in small ( 0.04 ha) gaps compared to ones of 0.12 and 0.4 ha [41]. However, as noted by Paterson [42], for at least three decades very little research and development was undertaken to develop these observations into a framework which would allow objective consideration of the potential role of CCF in Sitka spruce dominated forests in upland Britain.

Malcolm et al. [9] identified three preconditions for success of transforming plantation forests and several constraints. The preconditions were: the availability of adequate seed for natural regeneration; an 
adequate within stand microclimate for the establishment of natural regeneration or under-planted trees; and an appropriate silvicultural system that delivered both the seed supply and the desired microclimate. Based on their characterisation of Sitka spruce as a species of intermediate shade tolerance, they proposed [9] (table 3), that an irregular shelterwood system would be most appropriate for transforming forests of this species, using a gap size of $0.1-0.2$ ha. The main constraints identified were: the loss of the regeneration niche through vegetation competition; the potential damage to regenerating seedlings from browsing animals, particularly deer; and the risk of wind damage consequent upon opening up the mature stands to develop regeneration.

Over a decade has elapsed since that review and an appreciable amount of further research has been undertaken in the British Isles to investigate some of these preconditions and constraints such as seedling growth in the understorey and the wind stability of less regular stands. In addition, a number of operational trials have been undertaken to explore the feasibility of transforming conifer planted forests, including those dominated by Sitka spruce, to more diverse and irregular structures [19,43-46]. This paper summarises the major findings from these studies and trials, considers the knowledge gaps that still remain, and evaluates the practical implications for forest management.

\section{Aspects of Seedling Growth}

\subsection{Minimum Light Environment}

Several studies have examined the survival and growth of Sitka spruce seedlings in relation to light climate [46-52]. These used a mixture of greenhouse and nursery studies or field trials of varying duration (Table 1) to try to determine the most favourable understorey environment for regenerating or under-planted seedlings. While there is appreciable variation between the detailed findings of these trials, one of the main trends apparent from Table 1 is the need for a minimum relative light intensity (RLI) of around $20-25 \%$ of full light to ensure adequate seedling survival and growth. These findings are in line with modelling predictions [53] which indicated that a minimum of $20 \%$ transmittance would be necessary for seedling survival under a canopy. The various trials also suggest that optimal conditions for early survival and growth of Sitka spruce seedlings are likely to be found in conditions of about 50-60\% RLI, since under full light seedlings may suffer from frost damage [46] or from moisture stress due to higher evaporative demand [47]. The few comparisons of growth and survival of Sitka spruce and other species under a range of light conditions [46,49] tended to confirm the categorisation of Sitka spruce as having only intermediate shade tolerance. However, this finding was clearer from trials carried out for several years under field conditions [46] than from short-term nursery trials [49].

\subsection{Impacts of Aphids and Other Insects}

Seedlings growing under a mature spruce canopy are potentially at risk of defoliation by the green spruce aphid (Elatobium abietinum Walker), the main defoliator of mature Sitka spruce in the British Isles [54]. Bertin et al. [55] examined the interaction between aphid defoliation and light environment in a nursery study. They found that aphid densities were higher under 24\% RLI than in full light and that, after two years, there was a reduced leader length and a lower needle biomass in plants grown under shade and 
infested by aphids. These nursery studies were supported by surveys in forests with different stand structures which found higher populations of E. abietinum on regenerating spruce seedlings in shaded understorey environments than in lighter ones [56]. The implication is that, in years with high aphid densities, serious defoliation of regenerating seedlings can occur which could result in high mortality if the seedlings were already growing in a shaded environment close to their light compensation point.

Table 1. Summary of studies carried out in the British Isles since 2000 to investigate the response of Sitka spruce seedlings to understorey light conditions.

\begin{tabular}{|c|c|c|c|c|c|}
\hline Authors & $\begin{array}{l}\text { Location } \\
\text { of Study }\end{array}$ & $\begin{array}{l}\text { Duration } \\
\text { (Years) }\end{array}$ & $\begin{array}{c}\text { Light Treatments } \\
\text { Contrasted }^{1} \text { (\% Full } \\
\text { Light) }\end{array}$ & $\begin{array}{c}\text { Planted or } \\
\text { Regeneration }\end{array}$ & Main Results \\
\hline [46] & Forest & 4 & $100,61,16,2$ & Planted & $\begin{array}{l}\text { Highest survival at } 61 \% \text {, no survival } \\
\text { at } 2 \% \text {, with } 100 \% \text { and } 16 \% \\
\text { intermediate. Growth declines with } \\
\text { decreasing light. }\end{array}$ \\
\hline$[47]$ & Glasshouse & 1 & 100,50 & Planted & $\begin{array}{l}\text { Plants growing under shade showed } \\
\text { reduced photodamage and quicker } \\
\text { recovery of photosynethesis rates. }\end{array}$ \\
\hline$[48]$ & Forest & 5 & $55-5^{2}$ & $\begin{array}{l}\text { Planted and } \\
\text { regeneration }\end{array}$ & $\begin{array}{l}\text { Surviving planted seedlings only } \\
\text { found in gaps where RLI }>25 \% \text {. } \\
\text { Best growth in highest RLI. }\end{array}$ \\
\hline [49] & Nursery & 2 & $100,75,50,25$ & Planted & $\begin{array}{l}\text { No differences in survival. Height } \\
\text { increment greater at } 75 \% \text { and } \\
50 \% \text { RLI than in other treatments. }\end{array}$ \\
\hline$[50]$ & Nursery & 2 & $100,24^{3}$ & Planted & $\begin{array}{l}\text { No differences in survival. Lower } \\
\text { biomass in } 24 \% \text { RLI. }\end{array}$ \\
\hline$[57]$ & Forest & $5-7$ & $12,9,6^{5}$ & Planted & $\begin{array}{l}\text { After two years survival was highest } \\
\text { in the highest RLI. After } 7 \text { years no } \\
\text { survivors in any treatment. }\end{array}$ \\
\hline$[51]$ & Forest & 1 & $23,17^{4}$ & Regeneration & $\begin{array}{l}\text { Extension growth five times higher in } \\
23 \% \text { RLI. }\end{array}$ \\
\hline$[52]$ & Forest & 1 & $29,12^{4}$ & Regeneration & $\begin{array}{l}\text { Regenerating seedlings twice as tall } \\
\text { under } 29 \% \text { RLI. }\end{array}$ \\
\hline
\end{tabular}

Notes: ${ }^{1}$ Some of the studies assessed light regime through canopy openness rather than using a direct measure of relative light intensity. For simplicity, in this table they are all expressed as relative light intensity; ${ }^{2}$ In this study, light environment was assessed as canopy openness across a series of small gaps; ${ }^{3}$ This study contained a wider range of relative light intensities $(100,61,38,24,22,15)$ but only two were reported in the publication; ${ }^{4}$ These studies took place on naturally regenerated seedlings under canopies of varying densities;

5 This study involved underplanting in a stand thinned twice to provide basal areas of 34,29 and $24 \mathrm{~m}^{2} \mathrm{ha}^{-1}$.

By contrast, first principles suggested that Sitka spruce seedlings regenerating under a canopy should be less vulnerable to attack by the large pine weevil (Hylobius abietis L.) which causes serious damage to conifer seedlings planted to re-establish forests after clear felling [58]. An experiment was established in 2002 to look at the incidence of Hylobius damage to Sitka spruce planted on a clear felled site or under Sitka spruce stands thinned to different basal areas [44]. Within one year of planting, high numbers of Hylobius were present on the clear felled site with much lower levels present under the mature stands. 
At the end of the first season, there was extensive damage to the seedlings on the clear felled area compared to negligible impact on the seedlings under the canopy (Table 2). This trend was also evident in the second year when mortality of the seedlings on the clear-fell exceeded $90 \%$. The reasons for the lack of damage on the under-planted seedlings are thought to be the lack of stumps to act as breeding sites plus the greater availability of other woody material for the weevils to browse in the mature stands including the branches and foliage of the overstorey trees (pers. comm. R. Moore, Forest Research).

Table 2. Incidence of damage from Hylobius abietis on Sitka spruce transplants planted on a clear felled area or under a canopy of mature Sitka spruce trees (adapted from Mason et al. [44]).

\begin{tabular}{cccccccc}
\hline \multirow{2}{*}{ Treatment } & Basal Area & Light & Number & of & \multicolumn{2}{c}{ Hylobius } & \multicolumn{2}{c}{ Level of Damage (\%) } \\
\cline { 5 - 7 } & $\left(\mathbf{m}^{\mathbf{2}} \mathbf{h a}^{-\mathbf{1}}\right)$ & Transmittance (\%) & Trapped (May-October) & None & Slight & Dead \\
\hline Clear fell & - & 100 & 1230 & 1 & 34 & 65 \\
Mature, thinned $^{1}$ & 40 & 15 & 274 & 94 & 2 & 4 \\
\hline
\end{tabular}

Notes: ${ }^{1}$ The values presented for the mature stands are the average of three separate thinning treatments presented by Mason et al. [44].

\section{Stand Microclimate}

Given that other studies (see above) had identified that Sitka spruce was a species of intermediate shade tolerance, an area of interest was to determine how the understorey light climate was influenced by stand and canopy structure. Preliminary studies $[59,60]$ indicated that, in regular Sitka spruce stands, a basal area of around $30 \mathrm{~m}^{2} \mathrm{ha}^{-1}$ was required to provide a satisfactory light environment for the growth of regenerating seedlings. This suggestion was followed up in several studies examining the light transmittance through canopies of different stocking densities. Hale et al. [61] summarised results from 36 plots in six different Sitka spruce forests in upland Britain. These confirmed that, while a basal area of $30 \mathrm{~m}^{2} \mathrm{ha}^{-1}$ or less was associated with a favourable light environment for Sitka spruce natural regeneration, this basal area figure on its own was an insufficient predictor of adequate light transmittance and the interaction with stocking density should be considered. At a basal area of $30 \mathrm{~m}^{2} \mathrm{ha}^{-1}$ there needed to be a stocking density of $<450$ stems $^{-1}$ to provide the minimum $20 \%$ transmittance necessary for adequate seedling growth. This was because the high leaf area characteristic of Sitka spruce stands could reduce transmittance below critical levels unless a lower stocking density had provided sufficient tree clumping and irregularity in the canopy to increase light penetration to the forest floor. The combined contribution of basal area and stocking density as predictors of an adequate light environment for natural regeneration is also supported by Bertin et al. [51] where poorer growth of regeneration was evident in more densely stocked stands with lower transmittance values. These critical parameters may also need to be adjusted for different climates or regions since studies in Ireland suggested 5-10\% lower transmittance for a given basal area [57] (figure 6), than was found in equivalent British studies [61]. Time since thinning will also be important because the canopy gaps and more heterogeneous canopy resulting from a recent thinning will lead to a higher RLI: this decreases with time as the canopy closes [62].

By contrast, there have been few investigations of other aspects of the understorey microclimate of Sitka spruce stands. Sellars [63] used the site of the seedling growth study of Mason et al. [46] to examine the effect of different stand densities upon air and soil temperatures as well below canopy wind speed. 
She found that increased canopy openness resulted in higher irradiance, greater wind speed and more pronounced fluctuations in air temperature, especially near the ground (Table 3). A retained canopy was able to buffer the effects of heat loss to the sky during an autumn frost event. In the open area, night temperatures during this event fell to $-11{ }^{\circ} \mathrm{C}$, sufficient to cause serious damage to shoots if preceded by a period of warmer weather [64]. By contrast, in the stands with 156 and 278 stems ha $^{-1}$, the minima recorded were -4.3 and $-2.9^{\circ} \mathrm{C}$ respectively, temperatures which would likely cause little damage to regenerating seedlings. In one Irish study site with three stocking densities varying from 24 to $34 \mathrm{~m}^{2} \mathrm{ha}^{-1}$ [57], the highest soil temperature recorded was in the stand with the lowest basal area, while soil water content also tended to be higher in this treatment.

Table 3. Selected characteristics of the microclimate underneath a Sitka spruce stand in southern Scotland thinned to different densities (adapted from Sellars, [63]).

\begin{tabular}{|c|c|c|c|c|c|}
\hline $\begin{array}{l}\text { Treatment } \\
\left(\text { Stems ha }^{-1}\right)\end{array}$ & $\begin{array}{c}\text { Canopy } \\
\text { Openness (\%) }{ }^{1}\end{array}$ & $\begin{array}{c}\text { Mean Air } \\
\text { Temperature } \\
\text { @ } 0.23 \mathrm{~m} \\
\left({ }^{\circ} \mathrm{C}\right)^{2}\end{array}$ & $\begin{array}{c}\text { Difference between } \\
\text { Maximum and } \\
\text { Minimum Air } \\
\text { Temperatures } \\
\text { a } 0.23 \mathrm{~m}\left({ }^{\circ} \mathrm{C}\right)^{3} \\
\end{array}$ & $\begin{array}{c}\text { Soil Temperature } \\
\text { at } 0.05 \mathrm{~m} \text { Below } \\
\text { Ground }\left({ }^{\circ} \mathrm{C}\right)^{2}\end{array}$ & $\begin{array}{c}\text { Mean } \\
\text { Windspeed (\%) } \\
@ 1.05 \mathrm{~m}^{4}\end{array}$ \\
\hline 625 & 0.6 & 14.7 & 5 & - & 12 \\
\hline 278 & 4.8 & 15 & 6.4 & 13.6 & 6 \\
\hline 156 & 28.2 & 16.1 & 14.7 & 14.6 & 34 \\
\hline Open & 100 & 15.6 & 22.8 & 13.2 & 100 \\
\hline
\end{tabular}

Notes: ${ }^{1}$ Calculated as the average of 4 hemispherical photographs per treatment; ${ }^{2}$ The average value recorded over a $24 \mathrm{~h}$ period on a sunny day in August 2002; ${ }^{3}$ Difference between the average values recorded on the same day in August 2002; ${ }^{4}$ Expressed as a percentage of the windspeed value recorded in the open ground.

\section{Wind Stability of Irregular Stands}

The extent of adoption of CCF in Sitka spruce forests is heavily influenced by the perceived risk of windthrow, widely recognised as the major constraint upon the silvicultural options in forests in Britain and Ireland $[27,65]$. The initial recommendation was that CCF was best confined to sheltered sites on deep rooting soils where thinning at regular intervals could be used to gradually open up stands and provide a favourable regeneration environment [9]. A review of evidence about the stability of irregular stands [66] suggested that this recommendation might be pessimistic, since it overlooked the likelihood that dominant trees in irregular stands would be better adapted to withstand the forces of the wind, evidenced in more favourable (lower) height: diameter ratios, greater root mass, and stronger buttressing. Some preliminary modelling using the wind risk model ForestGALES [67] supported this suggestion, indicating that irregular structures could be more stable than regularly thinned even-aged stands on sites of intermediate wind exposure and that heavy early thinning might be used to develop stable dominants as part of the transformation process $[66,68]$. A wind tunnel examination of the effect of different stand structures (even-aged, shelterwood, selection) upon the incidence of damaging gusts found similar wind and turbulence characteristics over the different types. However, in this study the dominant trees in the structure representing a selection forest were exposed to more extreme wind loading than occurred in a regular stand, but the smaller trees in irregular structures were sheltered from these extremes [69]. 
In addition, the presence of an understorey, as might be found in a group selection forest, reduced the wind loading on the overstorey trees, possibly by limiting the amount of sway [69].

Some of these factors were examined in a 54 years-old stand on an exposed site in Clocaenog forest in Wales undergoing transformation to CCF [70] where the trees had proved considerably more wind stable than predicted [71]. Investigation of the wind forces and critical turning moment (the force required to overturn or break a tree) for nine individually instrumented trees of different size and canopy status (i.e., dominant, co-dominant, sub-dominant, suppressed) [72] (Table 2) showed a wider range of wind-tree interactions than in regular stands. Adaptive growth of individual trees had provided a balance between tree exposure to wind and the resistance to this force. The wind environment of individual trees was formalised using competition indices to characterise their status in the stand. Analysis of over $300 \mathrm{~h}$ of measurements for each tree showed a negative and broadly linear relationship between the turning moment calculated for an individual tree and its social status as estimated by a range of competition indices [72]. In other words, trees in the suppressed or subdominant classes had lower turning moments than dominants.

The relationship between turning moment and competition index calculated for an individual tree was used to predict the critical wind speed for tree failure for all trees in a 0.5 ha subplot of the Clocaenog stand both without thinning and when subjected to four different simulated thinning regimes (i.e., where trees might have a different competition index value as a result of neighbouring tree removal). All regimes were constrained to remove no more than $20 \%$ of the standing basal area and there was a proviso that no trees should be harvested adjacent to ones already selected for thinning to avoid the creation of gaps. The regimes were: from above-removal of the tallest trees in the stand; from below-removal of the smallest trees in the stand; neutral-removal of the same proportion of trees in each $3 \mathrm{~cm}$ dbh class; frame-tree-divide the stand into 64 blocks of equal size, identify the most stable tree based on height: diameter ratio and remove its immediate competitor. The simulated thinnings removed between 24 and 40 trees from the subplot representing around $19-23 \%$ of standing basal area. The effect of the different regimes was explored by showing the frequency distribution of all trees in the stand against critical wind speed (Figure 1). All thinning regimes caused some decrease in the overall stability of the stand compared to the unthinned state, which is shown by there being proportionately more trees in the lower wind speed classes after thinning and fewer in the higher classes. However, there were also some interesting differences between the thinning regimes, where the frame-tree thinning tended to provide a higher proportion of trees than other regimes in the higher wind speed classes between 14 and 18 metres s${ }^{-1}$. By contrast, thinning from above or neutral thinning had a higher proportion of trees in the lower wind speed classes [71].

The implication of these findings is that, while all thinning will increase the vulnerability of a stand to wind until the remaining trees have adapted to their changed wind loading, the type, intensity and frequency of thinning can affect the increase in risk. Parallel observations from the wider transformation trial area in Clocaenog forest supported these conclusions [73], since there was clear difference between treatments in the incidence of windthrow in both 2005 and 2007 with the highest incidence of windthrow recorded in a treatment which had inadvertently caused the removal of the most stable trees (frame-trees) within the stand (Table 4). A modelling study in the Aberfoyle Research Forest also showed that thinning from above which removed stable dominants could have a detrimental effect on stand stability [74]. 


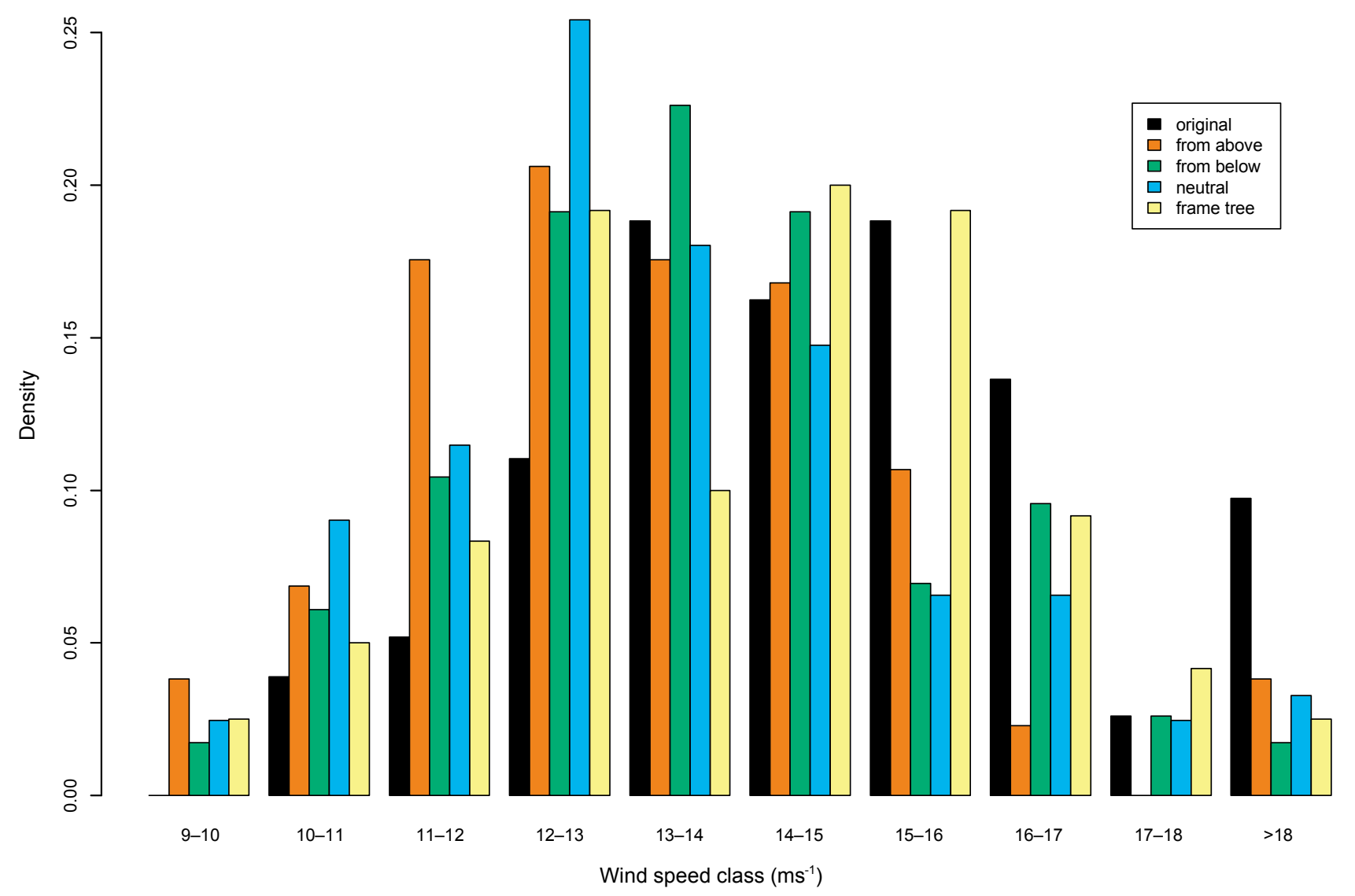

Figure 1. Distribution (density) of calculated wind speeds causing tree failure in the range $10-18 \mathrm{~m} \mathrm{~s}^{-1}$ for the experimental stand in Clocaenog Forest for the unthinned (original) stand and after the application of four different simulated thinning scenarios (see text for details).

Table 4. Effect of thinning to implement different silvicultural approaches upon subsequent wind damage in the Clocaenog research area (after Haufe, [73]).

\begin{tabular}{ccc}
\hline Treatment & $\begin{array}{c}\text { Basal Area }\left(\mathbf{m}^{\mathbf{2}} \mathbf{h a}^{-\mathbf{1}}\right) \text { after } \\
\text { Thinning in 2004 }\end{array}$ & $\begin{array}{c}\text { Cumulative Per Cent of Wind } \\
\text { Blown Trees in 2005-2007 }\end{array}$ \\
\hline Control-unthinned & 30.3 & 0.4 \\
Uniform shelterwood & 27.0 & 0.6 \\
Group shelterwood & 25.3 & 0.6 \\
Irregular shelterwood & 25.4 & 1.3 \\
Frame trees felled & $<27.0$ & 10.1 \\
\hline
\end{tabular}

Note: Three gales were recorded in January and February 2005 with a highest hourly mean wind speed of 16.5 metres $\mathrm{s}^{-1}$ while one gale was recorded in January 2007 with a highest hourly mean wind speed of 35.0 metres s $^{-1}$.

\section{Operational Aspects}

\subsection{Timber Quality}

Given the role of Sitka spruce forests as the main supplier of timber to the processing sector in the British Isles, it is important to understand the potential impacts of a substantial adoption of CCF upon the properties of the timber produced. Unfortunately, few studies have yet been undertaken in Britain to 
examine this issue, and the topic was not mentioned in a recent review of the wood properties of Sitka spruce and interaction with silviculture [75]. Macdonald et al. [76] carried out a modelling study to consider the potential impacts of different transformation scenarios to CCF upon Sitka spruce wood properties. They concluded that CCF had the potential to produce high quality spruce timber, not least because the longer rotations of the retained overstorey trees would result in a reduction in the amount of juvenile wood and in increased wood density. However, there could be increased variation in within-tree properties, particularly in trees growing on the edge of regeneration gaps. They suggested that the main impact of transformation of even-aged Sitka spruce stands to CCF would be to increase the range of tree sizes and products that were produced from a stand.

More recently, Cameron et al. [77] have investigated the wood properties of naturally regenerated Sitka spruce trees that had either grown in dense stands or had been respaced at an early age to normal plantation spacing. They found appreciable variation in properties between the juvenile and mature wood of the respaced trees, with the former having lower density and Modulus of Elasticity (MoE). By contrast, no such differences were found in the trees that had developed in dense thickets of natural regeneration, although these trees did have higher levels of compression wood. The authors suggested that appropriate management of natural regeneration to maintain timber quality should allow natural self-thinning in the early years to limit the impact of the juvenile core with subsequent thinning to favour better formed dominants. While these conclusions were derived from natural regeneration after clear felling, they are potentially applicable to natural regeneration in gaps or under a canopy. Indeed, Piisapanen et al. [78] reported that a reduced juvenile core with higher wood density was characteristic of natural regeneration of Norway spruce (Picea abies (L.) Karst.) in both even-aged and uneven-aged stands.

\subsection{Growth Models}

As the biological feasibility of transforming Sitka spruce stands to CCF has become apparent (e.g., abundant natural regeneration, better understanding of seedling light requirements, development of appropriate thinning regimes, etc.), so there has been an increasing recognition of the need to develop growth models that were capable of predicting both stand level and individual tree growth response to the more variable conditions characteristic of irregular stands [44,79]. Several studies have now been carried out to check the potential utility of different single tree distance dependant growth models to predict the development of irregular Sitka spruce stands, using models imported into Britain from other countries [52,79]. The model at the most advanced stage of development is MOSES GB [80], which is derived from the model MOSES originally developed for use with Norway spruce and other species in Austria [81]. The model has been parameterised for SS growing in Britain and adapted to reflect differences in data availability. Work is ongoing to validate the overall model as well as some of the concepts underpinning it, for example testing that the methods applied to predict tree height from dbh are appropriate under British conditions [82]. A number of long-term growth and yield plots have been established since 2000 in Sitka spruce stands undergoing transformation to CCF [44,70] which should prove helpful in testing model predictions. 


\subsection{Harvesting and Management Considerations}

An overview of experience in three Sitka spruce dominated forests that formed part of the Forestry Commission's National Network of CCF trial areas suggested that managers had generally managed successfully to adapt conventional mechanical harvesting practices for use in transformation thinning [83]. Common issues that emerged were: the difficulty with mechanical harvesting of the larger $(>55-60 \mathrm{~cm} \mathrm{dbh})$ trees that were present in the overstorey of CCF stands including coping with the large buttresses frequently found on the dominant trees; a requirement for improved guidance on the management of the dense natural regeneration that characterised many of these stands; the difficulty of implementing crown thinning and/or frame tree selection during the transformation process because machine operators found it difficult to see tree crowns from the harvester cabs, especially during short winter days; and the difficulties of extracting timber from CCF stands on wetter soils using permanent racks without causing serious rutting damage to the soils.

Subsequent investigations have found ways of limiting the impact of several of these issues. For instance, combining motor manual felling with mechanical harvesting was able to circumvent the problems caused by large diameter trees, where the motor manual operator felled trees beyond the capacity of the harvester head or which were otherwise problematic because of buttressing or large coarse branches [84]. Analysis of existing experiments on the management of dense natural regeneration has shown that early, selective respacing to around 2000 stems $^{-1} a^{-1}$ when trees are 2-4 m tall will improve subsequent stability compared to unrespaced controls and can provide some improvement in stem quality [37]. The effect of harvesting of overstorey trees on the density of Sitka spruce advance regeneration has also been examined [85] and although the felling and extraction killed or damaged over $50 \%$ of the regeneration, the amount of surviving seedlings and saplings was more than adequate to provide for future recruitment into the canopy layers. The construction of permanent racks using branches and small roundwood ("corduroy racks") offered a means of providing permanent access over wet soils, although renewing these in the longer term may still prove problematic because the lower stockings characteristic of the later stages of transformation may limit the amount of brash available to construct access racks [83].

\subsection{Costs of Transformation}

Along with the need to be able to predict the growth of stands transformed to CCF has come an increasing demand for improved information on the operational costs that might be incurred. An important source of information was a comparative study on the productivity of operations carried out in a 37 years-old even-aged stand of Sitka spruce in mid-Wales where conventional management options (clear felling, low thinning) were contrasted with some that might feature in transformation to CCF (group felling, frame-tree thinning, target diameter felling) [86,87]. The results indicated that all CCF operations were more costly than clear-felling, but there were appreciable differences between the types of transformation thinnings with costs lower in operations which removed the larger diameter trees (target diameter and frame-tree) which also provided a higher sawlog outturn (Table 5). An attempt to perform a wider cost-benefit analysis of transformation to CCF suggested that the outcome was sensitive to several assumptions, particularly those made about the magnitude of increased costs 
associated with CCF and the amount of cost reduction associated with the establishment of successful natural regeneration.

Table 5. Comparative harvesting outputs, sawlog outturn, and costs of standard operations and different transformation thinnings in a 37-years-old Sitka spruce stand (adapted from Price and Price, [87] (table 2 and figure 4)).

\begin{tabular}{cccccc}
\hline Treatment & $\begin{array}{c}\text { Basal Area before } \\
\text { Thinning }\left(\mathbf{m}^{\mathbf{2}} \mathbf{h a}^{-\mathbf{1}}\right)\end{array}$ & $\begin{array}{c}\text { Per Cent Basal } \\
\text { Area Removed }\end{array}$ & $\begin{array}{c}\text { Harvesting Time } \\
\left(\mathbf{m i n} \mathbf{~ m}^{-\mathbf{3}}\right)\end{array}$ & $\begin{array}{c}\text { Sawlog Per } \\
\mathbf{C e n t}\end{array}$ & $\begin{array}{c}\text { Cost } \\
\left(\mathfrak{f} \mathbf{~ m}^{-\mathbf{3}}\right)\end{array}$ \\
\hline Clear felling & 46.1 & 100 & 6.5 & 81.0 & 9.7 \\
Low thinning & 44.9 & 20.5 & 10.5 & 73.0 & 13.0 \\
Group felling & 43.9 & 19.4 & 7.7 & 74.0 & 12.8 \\
Frame tree thinning & 42.8 & 19.6 & 7.0 & 81.5 & 11.4 \\
Target diameter thinning & 39.3 & 21.8 & 7.7 & 87.0 & 10.0 \\
\hline
\end{tabular}

These and other results were used by Davies and Kerr [88] to compare the costs and revenues incurred by different strategies for transforming an even-aged Sitka spruce stand to CCF. Analysis began at 25 years and compared discounted revenue over periods of 20 years, 100 years, and to infinity. The strategies compared were transformation to a simple structure with or without successful natural regeneration, and transformation to a more complex stand structure. The results again highlighted the importance of successful natural regeneration for the evaluation, since when regeneration was successful, the CCF options were either more or as profitable as conventional even-aged management. If natural regeneration failed, then conventional management was substantially more profitable. In the short-term (i.e., 20 years), all CCF options were more attractive because the heavier crown thinnings provided a larger mean tree size than the low thinning regime associated with even-aged management.

\section{Discussion}

Recent decades have seen increasing interest in the potential role of CCF as an approach to forest management in many parts of the world $[18,89]$. However, there are few reports of CCF being actively deployed in the management of planted forests of non-native species since these are normally intensively managed for wood production using even-aged management. Although various policy documents were supporting wider use of CCF in planted forests in Britain by the late 1990s [9], recent analysis indicates that uptake of this approach is still limited and is mainly confined to forests where aspects such as recreation, amenity and biodiversity are high on the list of objectives $[19,20]$. Nevertheless, recent concerns about the potential vulnerability of single species plantations to the impacts of climate change [13] or to the spread of pests and diseases [90] raises the question as to whether CCF can be considered as a more resilient approach for management of planted forests. For the purposes of this discussion, it is assumed that the decision to use an alternative approach such as CCF depends as much upon its technical feasibility as its theoretical ability to deliver a range of ecosystem services.

The results reviewed in this paper illustrate the suite of information requirements and research challenges that need to be overcome if an alternative approach is to be successfully introduced into the management of planted forests, such as those of Sitka spruce in the British Isles. There are at least 15 different aspects of stand management where information has been required to elucidate the potential 
role of CCF in the management of planted forests of Sitka spruce (Table 6). These can be broadly grouped into three categories covering: the establishment of natural regeneration; the tending of the stands to develop irregular structures; and various operational aspects. Examination of the quality of the evidence (Table 6) suggests that much useful information has been gained about the requirements for successful natural regeneration of Sitka spruce so that managers can begin to predict with some confidence those sites and stands where regeneration can be anticipated, and the measures that can be taken to foster it when it occurs. Similarly, "good" to "moderate" evidence has been obtained on some of the key operational aspects that will influence the uptake of CCF, such as the ability to use conventional harvesting systems, the potential impacts on timber quality, and the cost and revenue implications of using an alternative silvicultural approach to patch clear-felling.

By contrast, in the stand tending group there are several stages where the quality of evidence is classed either as "poor" or "poor-moderate" and thus could limit the uptake of CCF. A couple of these stages involve the wind stability of irregular stands and the interaction with thinning where concern over the potential wind risks associated with the introduction of CCF may limit forest managers' willingness to adopt this alternative silvicultural approach [91]. The rating of this evidence is, at least in part, a reflection of improved knowledge. Thus, when guidance on CCF was first provided, there were strong caveats against using this approach on more exposed sites where windthrow was expected to be a problem $[9,17]$. This reflected a deterministic approach to wind risk management which believed that there was relatively little that silviculture could do to mitigate wind damage which would be determined by a combination of site and climate [27]. The pessimism about the potential role of CCF on more exposed sites would also have been reinforced by the tendency of early versions of ForestGALES and previous methods of evaluating wind risk to over-predict the occurrence of wind damage [92]. However, the results reported here [71,72] indicate not only that it is possible to develop and maintain irregular structures on more exposed sites than previously thought, but also that the use of crown thinning regimes which develop and favour the most stable trees in the stand may confer enhanced resistance to strong winds, provided that the retained trees have adapted to an increased wind loading following thinning. The retention of these dominant "frame" trees should also limit any risk that removal of other vigorous trees in crown thinning might degrade the genetic potential of the stand. Similar stability benefits from wind-adapted thinning regimes have been reported in Norway spruce stands in the Czech republic where heavy thinning at top heights of 10-15 m improved the sturdiness (h:d) ratio of retained trees compared to unthinned controls [93]. The effect of thinning type was also found in study of storm damage in southern Germany where increased windthrow risk was incurred by removal of stable dominant trees in thinning [94]. 
Table 6. The main stages involved in evaluation of the feasibility of introducing CCF into the management of Sitka spruce planted forests in Britain, together with conclusions on the present situation and an assessment of the quality of the supporting evidence.

\begin{tabular}{|c|c|c|c|}
\hline Stage & Conclusion & Evidence Quality & Main References \\
\hline \multicolumn{4}{|l|}{ NATURAL } \\
\hline \multicolumn{4}{|l|}{ REGENERATION } \\
\hline Seed availability & Mast years recorded in British Sitka spruce stands every $4-5$ years & Good-moderate & {$[9,95]$} \\
\hline Germination conditions & Favourable conditions involve moist soils with needle litter, light moss cover & Moderate-poor & [9] \\
\hline $\begin{array}{l}\text { Light requirements for growth of } \\
\text { young seedlings }\end{array}$ & $\begin{array}{l}\text { At least } 20 \% \text { RLI plus a canopy with gaps equivalent to basal area of } 30 \mathrm{~m}^{2} \mathrm{ha}^{-1} \text { and a } \\
\text { reduced stand density }\end{array}$ & Good & Table $1 ;[61]$ \\
\hline $\begin{array}{l}\text { Other aspects of understorey } \\
\text { microclimate }\end{array}$ & Retain some canopy cover to limit frost damage but provide adequate light & Moderate & {$[48,63]$} \\
\hline Vegetation competition & Avoid fertile sites or competition from ericaceous vegetation & Moderate & {$[9,96]$} \\
\hline Browsing pressure & $\begin{array}{l}\text { Keep deer population below } 5 \text { animals per } 100 \text { ha-lower levels necessary for admixed } \\
\text { species }\end{array}$ & Moderate & {$[9]$} \\
\hline \multicolumn{4}{|l|}{ STAND TENDING } \\
\hline $\begin{array}{l}\text { Management of established } \\
\text { regeneration }\end{array}$ & Respace to $c a .2000$ stems ha $^{-1}$ at 3-4 m height & Good & {$[37]$} \\
\hline Thinning type and intensity & $\begin{array}{l}\text { In young stands }(<25 \text { years old) use crown thinning to develop stability of selected } \\
\text { dominants. Intervention in older stands depends upon wind risk. }\end{array}$ & $\begin{array}{l}\text { Good-moderate for young stands; } \\
\text { poor-moderate for older stands }\end{array}$ & {$[71,72]$} \\
\hline $\begin{array}{l}\text { Vulnerability to abiotic } \\
\text { disturbance (e.g., wind) }\end{array}$ & $\begin{array}{l}\text { Use of CCF can be extended to sites of intermediate wind exposure if soils allow good } \\
\text { rooting and if stand will respond to thinning }\end{array}$ & Poor-moderate & {$[66,71]$} \\
\hline Formation of mixtures & $\begin{array}{l}\text { Gap environment required for Sitka spruce natural regeneration should favour } \\
\text { regeneration/underplanting of a range of species. Little knowledge of potential } \\
\text { long-term species for admixing with Sitka spruce. }\end{array}$ & Poor & {$[9]$} \\
\hline $\begin{array}{l}\text { Identification of appropriate } \\
\text { silvicultural system }\end{array}$ & $\begin{array}{l}\text { Irregular shelterwood proposed based on characterisation of Sitka spruce as having } \\
\text { intermediate shade tolerance }\end{array}$ & Poor-moderate & {$[9]$} \\
\hline $\begin{array}{l}\text { Knowledge of natural } \\
\text { stand dynamics }\end{array}$ & Wind disturbance a major driver of stand structures. Possible influence of deer browsing & Poor-moderate & {$[97,98]$} \\
\hline
\end{tabular}


Table 6. Cont.

\begin{tabular}{|c|c|c|c|}
\hline Stage & Conclusion & Evidence Quality & Main References \\
\hline \multicolumn{4}{|l|}{ OPERATIONAL } \\
\hline $\begin{array}{l}\text { Use of standard harvesting } \\
\text { systems/machinery }\end{array}$ & $\begin{array}{c}\text { The major problem encountered was the need to include motor manual } \\
\text { working to deal with large trees. The lack of brash availability may be } \\
\text { problematic in later thinnings on wet soils. }\end{array}$ & Good-moderate & {$[83,84]$} \\
\hline $\begin{array}{l}\text { Forecasting and monitoring of } \\
\text { growth of irregular stands }\end{array}$ & $\begin{array}{l}\text { A range of models evaluated and MOSES GB calibrated with promising results. } \\
\text { Monitoring system available for CCF stands. }\end{array}$ & Moderate & {$[45,80]$} \\
\hline $\begin{array}{l}\text { Availability of long-term growth } \\
\text { and yield data from irregular stands }\end{array}$ & $\begin{array}{l}\text { A series of plots have been established since } 2000 \text { in stands being transformed to } \\
\text { CCF. However only limited data have been published to date. }\end{array}$ & Poor-moderate & {$[44,70]$} \\
\hline Impacts on timber quality & $\begin{array}{l}\text { Modelling studies suggest limited impacts provided CCF stands } \\
\text { are carefully thinned. Further validation required. }\end{array}$ & Moderate & {$[76]$} \\
\hline Predicting costs and revenues & $\begin{array}{l}\text { Field experiments and modelling suggests CCF can be competitive with } \\
\text { standard management provided successful regeneration is obtained. } \\
\text { Links to wind risk need exploration. }\end{array}$ & Moderate & {$[86-88]$} \\
\hline Installation of field scale trials & At least three field scale trials of CCF installed in Sitka spruce dominated forests. & Good-moderate & {$[19,83]$} \\
\hline $\begin{array}{c}\text { Provision of other support } \\
\text { mechanisms e.g., training, subsidies. }\end{array}$ & $\begin{array}{l}\text { Training for foresters and operators available. Grant schemes available to private } \\
\text { growers more suited to even-aged management than CCF }\end{array}$ & Moderate & {$[19]$} \\
\hline
\end{tabular}

Notes: Evidence quality has been subjectively graded as follows: ${ }^{1}$ Poor-a few or no observational reports; no detailed studies; ${ }^{2}$ Moderate-some observational reports; very

few detailed studies; ${ }^{3}$ Good-frequent observational reports; several or more detailed studies. 
Although there is awareness of the possibility of fostering irregular stands on more exposed sites, it remains difficult to predict the potential risks involved. This will require a better understanding of how the wind loading on individual trees is altered by thinning, of how the loading changes subsequently as a result of adaptive growth, not to mention how these factors are affected by tree age and the social position of a tree within the stand. While much of this information can be obtained through field study, one aim should be to formalise the knowledge gained in an integrated modelling environment where the outputs of a wind risk model such as ForestGALES can be combined with those of a single tree growth model such as MOSES GB. Such integration would allow exploration of the type, timing and intensity of thinning to see when and how more stable structures might be developed in Sitka spruce stands on more exposed sites and what the distribution of risk might be to individual trees within the stand [74]. The results from such simulations, and from the long-term growth and yield plots, could also be used to gain further understanding of the potential effects of transformation to CCF upon financial returns and profitability, including the calculation of annuities [99]. This may require abandoning some traditional tenets of stand management based on average tree dimensions and stocking densities and moving towards a more spatially explicit form of management which recognises individual variation between and within stands [100].

Another stage with "poor" evidence quality involves the desirability of diversifying the species composition of Sitka spruce stands managed by CCF. Introduction of selected complementary species is recommended as a means of increasing the functional diversity of planted forests by enhancing their capacity to respond to unforeseen changes [31,101]. A number of under-planting trials with a range of conifer species have been installed recently in Sitka spruce stands and should provide guidance within a few years (pers. comm. Gary Kerr and Victoria Stokes, Forest Research). Evidence from field sites in Britain suggests that natural regeneration within mature stands is almost exclusively of Sitka spruce with only occasional broadleaves or other species $[50,85,97]$. Therefore any attempt to diversify the species composition of CCF stands will probably need to rely on under-planting to establish a future seed source. However, the fast and sustained height growth of Sitka spruce means that it is likely to suppress most broadleaves or other light demanding conifer species that may regenerate within gaps in a stand. This suggests that the species chosen as part of a diversification strategy should be intermediate or shade-tolerant broadleaves or conifers that can grow in the small gaps that develop in a CCF stand [9,102]. For instance, recent reviews have suggested that both western hemlock (Tsuga heterophylla (Raf.) Sarg.)) and a number of Abies species could be successfully under-planted in gaps in CCF stands [103,104]. The potential invasive effects of species such as western hemlock were thought to be limited, given the faster height growth of Sitka spruce [103]. One other functional trait that could be usefully explored is rooting habit where admixture with a deeper rooting species might improve stability of stands of Sitka spruce. For example, results from tree-pulling studies showed that grand fir (Abies grandis (Dougl. ex D. Don) Lindl.) had better anchorage on mineral soils than Sitka spruce [105].

As yet, there appears to be no consistent view as to the silvicultural system(s) that might be best suited to supporting the implementation of CCF in Sitka spruce planted forests. Malcolm et al. [9] recommended an irregular shelterwood as the preferred option based on the view that Sitka spruce was a species of intermediate shade tolerance. However, the operational trial area at Clocaenog contain stands managed using uniform and group/strip as well as irregular shelterwoods [70] and, as yet, there have been no major differences recorded in their effectiveness. A similar range of shelterwood systems have 
been reported from other trial areas [19]. Ideally, information from these trials would be complemented by information on the dynamics of structural development observed in stands of varying ages, as has recently been reported from the species' natural range in Alaska [106]. The limited studies that have been carried out revealed a range of wind-created gap sizes in a number of planted Sitka spruce forests [97,98]. Larger gaps ( $>0.03 \mathrm{ha})$ appeared to be filling with established natural regeneration of Sitka spruce, but presence of other species was limited, possibly because of browsing by deer or because of the lack of a seed source [97]. These findings suggest that, provided there is an adequate light environment for natural regeneration, Sitka spruce can be managed under CCF using a variety of silvicultural systems and gap sizes depending upon management objectives and other factors such as the incidence of wind risk. This potential flexibility of approach would accord with current thinking of embracing complexity in forest management [100].

\section{Conclusions}

Systematic research into CCF in the British Isles can be dated back to the mid 1990s after the revival of interest in this approach in forestry circles in the British Isles [43]. Formal policy support for the approach was first expressed in the late 1990s and has been maintained to the present day, but as noted above, the percentage of the forest area managed by CCF remains quite low, especially in planted conifer forests dominated by Sitka spruce. With the benefit of hindsight, this can be explained as an inevitable consequence of introducing a new approach to management into a resource which had been established using the simple, top-down rules that are characteristic of much plantation forestry in the modern world [107]. In the early stages of introducing an alternative management concept, there will be resistance to change until sufficient evidence and demonstrations are available to convince sceptics of the merits of the new approach [91]. This is despite accumulating evidence from modelling studies that a combination of species diversification and greater use of CCF (or the synonymous Low Impact Silvicultural Systems) is a prudent way of conferring greater resilience against projected climate change in Sitka spruce dominated forests [108]. Given that successful transformation of regular stands to irregular structures may take at least 50 years, as shown by the history of the Glentress trial area established in the 1950s [38,102], it is likely that there will need to be at least a decade of further research and development before CCF will be widely accepted as a credible way of managing a substantial area of the Sitka spruce planted forests in the British Isles. This review has suggested that the focus of future investigations should be on refining our understanding of factors affecting the wind stability of irregular stand structures and on identifying the species most appropriate for admixing in Sitka spruce forests, with an ultimate aim of increasing the resilience of these forests against the effects of an uncertain and changing climate.

\section{Acknowledgments}

I am grateful to many colleagues who have contributed to the ideas and studies presented in this paper, especially Owen Davies, Colin Edwards, Barry Gardiner, Sophie Hale, Duncan Ireland, Gary Kerr, Bruce Nicoll, and Victoria Stokes. I also wish to acknowledge the excellent work by members of Forest Research's Technical Support Unit in installing and maintaining various field trials. Catia Arcangeli and 
Sophie Hale provided very helpful comments on an early draft of the paper, which has been further improved by the suggestions of two anonymous referees.

\section{Conflicts of Interest}

The author declares no conflict of interest.

\section{References}

1. Joyce, P.M.; O'Carroll, N. Sitka Spruce in Ireland; COFORD: Dublin, Ireland, 2002; p. 201.

2. Mason, W.L. Changes in the management of British forests between 1945 and 2000 and possible future trends. Ibis 2007, 149, 41-52.

3. Malcolm, D.C. The silviculture of conifers in Great Britain. Forestry 1997, 70, 293-307.

4. Ponsoby, T.B. A system of forestry for the British Islands. Trans. R. Scott. Arboric. Soc. 1931, 45, $1-28$.

5. Penistan, M.J. The alternative to extensive regular clear-felling. Scott. For. 1952, 6, $18-21$.

6. Anderson, M.L. Plea for the adoption of the Standing Control or Check Method in Woodland Management. Scott. For. 1953, 7, 38-47.

7. Anderson, M.L. Norway spruce-silver fir-beech mixed selection forest: Is it possible to reproduce this in Scotland? Scott. For. 1960, 14, 87-93.

8. Johnston, D.R.; Grayson, A.J.; Bradley, R.T. Forest Planning; Faber and Faber: London, UK, 1967.

9. Malcolm, D.C.; Mason, W.L.; Clarke, G.C. The transformation of conifer forests in Great Britain-regeneration, gap size, and silvicultural systems. For. Ecol. Manag. 2001, 151, 7-23.

10. Humphrey, J.W.; Ferris, R.; Quine, C.P. Biodiversity in Britain's Planted Forests; Forestry Commission: Edinburgh, UK, 2003; p. 117.

11. Edwards, D.; Jay, M.; Jensen, F.S.; Lucas, B.; Marzano, M.; Montagne, C.; Peace, A.; Weiss, G. Public preferences for structural attributes of forests: Towards a pan-European perspective. For. Policy Econ. 2012, 19, 12-19.

12. Ray, D. Impacts of Climate Change on Forestry in Scotland-a Synopsis of Spatial Modelling Research; Forestry Commission Research Note 101; Forestry Commission: Edinburgh, UK, 2008; p. 8.

13. Kirby, K.J.; Quine, C.P.; Brown, N.D. The adaptation of UK forests and woodlands to climate change. In Combating Climate Change-A Role for UK Forests. An Assessment of the Potential of the UK's Trees and Woodlands to Mitigate and Adapt to Climate Change; Read, D.J., Freer-Smith, P.H., Morison, J.I.L., Hanley, N., West, C.C., Snowdon, P., Eds.; The Stationery Office: Edinburgh, UK, 2009; pp. 164-179.

14. Anonymous. Forests, Products and People: Ireland's Forest Policy-A Renewed Vision; Department of Agriculture, Food and the Marine: Dublin, Ireland, 2013; p. 99. Available online: http://www.agriculture.gov.ie/media/migration/forestry/publicconsultation/forestpolicyreview/Fo restPolicyReviewpublicconsult21Jun2013.pdf (accessed on 28 November 2014).

15. Forestry Commission Scotland. The Scottish Forestry Strategy; Forestry Commission Scotland: Edinburgh, UK, 2006. 
16. Forestry Commission Wales. Woodlands for Wales-The Welsh Assembly Government's Strategy for Woodlands and Trees; Forestry Commission Wales: Aberystwyth, UK, 2009.

17. Mason, W.L.; Kerr, G.; Simpson, J.M. What is Continuous Cover Forestry? In Forestry Commission Information Note 29; Forestry Commission: Edinburgh, UK, 1999.

18. Pommerening, A.; Murphy, S.T. A review of the history, definitions and methods of continuous cover forestry with special attention to afforestation and restocking. Forestry 2004, 77, 27-44.

19. Wilson, S.M. Adoption of alternative silvicultural systems in Great Britain: A review. Quart. J. For. 2013, 107, 279-293.

20. Vitkova, L.; Ni Dhubhain, A.; O’Tuama, P.; Purser, P. The practice of Continuous Cover Forestry in Ireland. Irish For. 2013, 70, 141-156.

21. MacDonald, J.; Wood, R.F.; Edwards, M.V.; Aldhous, J.R. Exotic Forest Trees in Great Britain; Forestry Commission Bulletin 30; HMSO: London, UK, 1957; p. 168.

22. Peterson, E.B.; Peterson, N.M.; Weetman, G.F.; Martin, P.J. Ecology and Management of Sitka Spruce, Emphasising Its Natural Range in British Columbia; UBC Press: Vancouver, Canada, 1997; p. 336.

23. Steven, H.M. Changes in Silvicultural Practice in Scotland 1854-1953. Scott. For. 1954, 8, 48-61.

24. Steven, H.M. The silviculture of conifers in Great Britain. Forestry 1927, 1, 6-23.

25. Mason, W.L.; Perks, M.P. Sitka spruce (Picea sitchensis) forests in Atlantic Europe: Changes in forest management and possible consequences for carbon sequestration. Scand. J. For. Res. 2011, $11,72-81$.

26. Malcolm, D.C. Some ecological aspects of Sitka spruce. Proc. R. Soc. Edinb. 1987, 93B, 85-92.

27. Quine, C.P.; Coutts, M.P.; Gardiner, B.A.; Pyatt, D.G. Forests and Wind: Management to Minimise Damage; Forestry Commission Bulletin 114; HMSO: London, UK, 1995.

28. McIntosh, R.M. The history and multi-purpose management of Kielder forest. For. Ecol. Manag. 1995, 79, 1-11.

29. Morgan, J.L.; Campbell, J.M.; Malcolm, D.C. Nitrogen relations of mixed-species stands on oligotrophic soils. In The Ecology of Mixed-Species Stands of Trees; Cannell, M.G.R., Malcolm, D.C., Robertson, P.A., Eds.; Blackwell: Oxford, UK, 1992; pp. 65-85.

30. Mason, W.L. Long-term development of nursing mixtures of Sitka spruce and larch species in an experiment in northern Scotland. For. Syst. 2014, 23, 590-597.

31. Paquette, A.; Messier, C. Managing tree plantations as complex adaptive systems. In Managing Forests As Complex Adaptive Systems; Messier, C., Puettmann, K.J., Coates, K.D., Eds.; Routledge: Abingdon, UK, 2013; pp. 299-326.

32. Penistan, M.J. Natural restocking in practice. Scott. For. 1950, 4, 49-55.

33. Macdonald, J.M.; Lockhart, S.F.M. Some early observations on the natural regeneration of conifers in Scotland. Scott. For. 1953, 7, 79-82.

34. McNeill, J.D.; Thompson, D.A. Natural regeneration of Sitka spruce in the Forest of Ae. Scott. For. 1982, 36, 269-282.

35. Von Ow, F.; Joyce, P.; Keane, M. Factors affecting the establishment of natural regeneration of Sitka spruce (Picea sitchensis (Bong.) Carr.) in Ireland. Irish For. 1996, 53, 2-18.

36. Mason, W.L. Natural regeneration of Sitka spruce in the Forest of Ae: Development over 25 years. Scott. For. 2008, 62, 2-8. 
37. Stokes, V.; Kerr, G. Long-term growth and yield effects of respacing natural regeneration of Sitka spruce in Britain. Eur. J. For. Res. 2013, 132, 351-362.

38. Anderson, M.L. A History of Scottish Forestry; volume 2, Thomas Nelson and Sons: London, UK, 1967; p.482.

39. Malcolm, D.C. Corrour management trial. Scott. For. 1971, 25, 262-270.

40. Penistan, M.J. Transforming plantations to forests. Scott. For. 1960, 14, 185-198.

41. Neustein, S.A. Windthrow on the Margins of Different Sizes of Felling Area; Report on Forest Research for the Year Ended March: London, UK, 1964; pp. 166-171.

42. Paterson, D.B. The potential to apply different silvicultural systems to upland British forests, predominately of Sitka spruce. In Silvicultural Systems; Gordon, P., Ed.; Institute of Chartered Foresters: Edinburgh, UK, 1990; pp. 120-138.

43. Hart, C. Alternative Silvicultural Systems to Clear Cutting in Britain: A Review; Forestry Commission Bulletin 115; HMSO: London, UK, 1995.

44. Mason, W.L.; Kerr, G.; Pommerening, A.; Edwards, C.; Hale, S.E.; Ireland, D. Continuous cover forestry in British conifer forests. For. Res. Ann. Rep. 2003-2004, 2005, 38-53.

45. Kerr, G. Managing Continuous Cover Forests; Operational Guidance Booklet 7; Forestry Commission: Edinburgh, UK, 2008; p. 64.

46. Mason, W.L.; Edwards, C.; Hale, S.E. Survival and early seedling growth of conifers with different shade tolerance in a Sitka spruce spacing trial and relationship to understorey light climate. Silva Fenn. 2004, 38, 357-370.

47. Black, K.; Davis, P.; McGrath, J.; Doherty, P.; Osborne, B. Interactive effects of irradiance and water availability on the photosynthetic performance of Picea sitchensis seedlings: Implications for seedling establishment under different management practices. Ann. For. Sci. 2005, 62, 413-422.

48. Page, L.M.; Cameron, A.D. Regeneration dynamics of Sitka spruce in artificially created forest gaps. For. Ecol. Manag. 2006, 221, 260-266.

49. Kennedy, S.; Black, K.; O'Reilly, C.; N1 Dhubhain, A. The impact of shade on morphology, growth and biomass allocation in Picea sitchensis, Larix x eurolepis and Thuja plicata. New For. 2007, 33, 139-153.

50. Bertin, S. Physiological Ecology of Understorey Trees in Low Impact Silvicultural Systems. Ph.D. Thesis, University of Edinburgh, Edinburgh, UK, June 2009; p. 176.

51. Bertin, S.; Palmroth, S.; Kim, H.S.; Perks, M.P.; Mencuccini, M.; Oren, R. Modelling understorey light for seedling regeneration in continuous cover forestry canopies. Forestry 2011, 84, 397-409.

52. Mackintosh, H. Developing the Silviculture of Continuous Cover Forestry: Using the Data and Experience Collected from the Glentress Trial Area. Ph.D. Thesis, University of Edinburgh, Edinburgh, UK, June 2013; p. 215.

53. Hale, S.E.; Levy, P.E.; Gardiner, B.A. Trade-offs between seedling growth, thinning and stand stability in Sitka spruce stands: A modelling analysis. For. Ecol. Manag. 2004, 187, 105-115.

54. Carter, C.; Halldórsson, G. Origins and background to the green spruce aphid in Europe. In The Green Spruce Aphid in Western Europe: Ecology, Status, Impacts and Prospects for Management; Day, K.R., Halldórsson, G., Harding, S., Straw, N.A., Eds.; Forestry Commission: Edinburgh, UK, 1998; pp. 1-10. 
55. Bertin, S.; Perks, M.P.; Straw, N.; Bertin, J.M.; Mencuccini, M. Green spruce aphid infestations cause larger growth reductions to Sitka spruce under shade. Tree Physiol. 2010, 30, 1403-1414.

56. Bladon, F.M. Green Spruce Aphid (Elatobium Abietinum) in a Changing Forest Environment: Population Patterns and Their Underlying Causes. Ph.D. Thesis, University of Ulster, Coleraine, Northern Ireland, UK, November 2010.

57. Ni Dhubhain, A. An Evaluation of Continuous Cover Forestry in Ireland; Coford, Department of Agriculture, Fisheries and Food: Dublin, Ireland, 2010; p. 40.

58. Leather, S.R.; Day, K.R.; Salisbury, A.N. The biology and ecology of the large pine weevil, Hylobius abietis (Coleoptora: Curculionidae): A problem of dispersal. Bull. Entomol. Res. 1999, 89, 3-16.

59. Hale, S.E. Light regime beneath Sitka spruce plantations in northern Britain: Preliminary results. For. Ecol. Manag. 2001, 151, 61-66.

60. Page, L.M.; Cameron, A.D.; Clarke, G.C. Influence of overstorey basal area on density and growth of advance regeneration of Sitka spruce in variably thinned stands. For. Ecol. Manag. 2001, 151, $25-35$.

61. Hale, S.E.; Edwards, C.; Mason, W.L.; Price, M.; Peace, A. Relationship between canopy transmittance and stand parameters in Sitka spruce and Scots pine stands in Britain. Forestry 2009, $82,505-513$.

62. Sonohat, G.; Balandier, P.; Ruchaud, F. Predicting solar radiation transmittance in the understory of even-aged coniferous stands in temperate forests. Ann. For. Sci. 2004, 61, 629-641.

63. Sellars, H.C. Undercanopy Microclimatology of Sitka Spruce Plantation Forests: Implications for Natural Regeneration. Ph.D. Thesis, University of Liverpool, Liverpool, UK, October 2005; p. 187.

64. Cannell, M.G.R.; Sheppard, L.J.; Smith, R.I.; Murray, M.B. Autumn frost damage on young Picea sitchensis 2. Shoot frost hardening, and the probability of frost damage in Scotland. Forestry 1985, $58,145-166$.

65. Ni Dhubhain, A.; Walshe, J.; Bulfin, M.; Keane, M.; Mills, P. The initial development of a windthrow risk model for Sitka spruce in Ireland. Forestry 2001, 74, 161-170.

66. Mason, W.L. Are irregular stands more windfirm? Forestry 2002, 75, 347-355.

67. Gardiner, B.A.; Suarez, J.; Achim, A.; Hale, S.E.; Nicoll, B.C. ForestGALES 2-A PC-Based Wind Risk Model for British Forests-User Guide; Forestry Commission: Edinburgh, UK, 2004.

68. Mason, W.L. Continuous Cover Forestry: Developing close-to-nature forest management in conifer plantations in upland Britain. Scott. For. 2003, 57, 141-149.

69. Gardiner, B.A.; Marshall, B.; Achim, A.; Belcher, R.; Wood, C. The stability of different silvicultural systems: A wind-tunnel investigation. Forestry 2005, 78, 471-484.

70. Davies, O. Background to the Clocaenog CCF Research Area, 2013; p. 4. Available online: http://www.forestry.gov.uk/pdf/Background_Clocaenog_ccf_research_area.pdf/\$FILE/Backgrou nd_Clocaenog_ccf_research_area.pdf (accessed on 16 December 2014).

71. Wellpot, A. The Stability of Continuous Cover Forests. Ph.D. Thesis, University of Edinburgh, Edinburgh, UK, October 2008; p. 160.

72. Hale, S.E.; Gardiner, B.A.; Wellpot, A.; Nicoll, B.C.; Achim, A. Wind loading of trees: Influence of tree size and competition. Eur. J. For. Res. 2012, 131, 203-217. 
73. Haufe, J. Sticking Your Head Out-the Social Status of Trees and Wind Risk: A Case Study from Clocaenog Forest. CCFG Newsletter 26, 2007; pp. 5-8. Available online: http://www.ccfg.org.uk/membersarea/archive/downloads/newsletters/CCFG_newsletter_26.pdf (accessed on 15 December 2014).

74. Suarez-Minguez, J.C. An Analysis of the Consequences of Stand Variability in Sitka Spruce Plantations in Britain Using a Combination of Airborne LiDAR Analysis and Models. Ph.D. Thesis, University of Sheffield, Sheffield, UK, February 2010; p. 285.

75. Moore, J.R. Wood Properties and Uses of Sitka Spruce in Britain; Forestry Commission Research Report; Forestry Commission: Edinburgh, UK, 2011; p. 48.

76. Macdonald, E.; Gardiner, B.; Mason, W. The effects of transformation of even-aged stands to continuous cover forestry on conifer log quality and wood properties in the UK. Forestry 2010, $83,1-15$.

77. Cameron, A.D.; Gardiner, B.A.; Ramsay, J.; Drewett, T.A. Effect of early release from intense competition within high density natural regeneration on the properties of juvenile and mature wood of 40-year-old Sitka spruce (Picea sitchensis (Bong.) Carr.). Ann. For. Sci. 2015, 72, 99-107.

78. Piispanen, R.; Heinonen, J.; Valkonen, S.; Makinen, H.; Lundqvist, S.O.; Saranpaa, P. Wood density of Norway spruce in uneven-aged stands. Can. J. For. Res. 2014, 44, 136-144.

79. Pommerening, A.; Wenk, G. Preliminary Study for a Flexible Growth Model to Predict the Consequences of CCF in Wales. In Continuous Cover Forestry. Assessment, Analysis, Scenarios; Gadow, K., Nagel, J., Saborowski, J., Eds.; Kluwer Academic Publishers: Dordrecht, Germany, 2002; pp. 231-251.

80. Jenkins, T. Modelling mixed-age and mixed species stands, 2014. Available online: http://www.forestry.gov.uk/fr/infd-8bxetz (accessed on 15 December 2014).

81. Hasenauer, H.; Kindermann, G.; Steinmetz, P. The tree growth model MOSES 3.0. In Sustainable Forest Management: Growth models for Europe; Hasenauer, H., Ed.; Springer: Berlin, Germary, 2006; pp. 64-70.

82. Arcangeli, C.; Klopf, M.; Hale, S.E.; Jenkins, T.A.R.; Hasenauer, H. The uniform height curve method for height-diameter modelling: An application to Sitka spruce in Britain. Forestry 2014, 87, 177-186.

83. Ireland, D. Operational experience of Continuous Cover forestry: UK case studies. In Forestry Commission Internal Project Information Note 13/06; Forestry Commission Technical Development, Ae: Dumfries, UK, 2006; p. 51.

84. Ireland, D. CCF Operational best practice: Final overstorey removal in uniform shelterwood. In Forestry Commission Internal Project Information Note 45/08; Forestry Commission Technical Development, Ae: Dumfries, UK, 2009; p. 17.

85. Stokes, V.; Kerr, G.; Ireland, D. Seedling height and the impact of harvesting operations on advance regeneration of conifer species in upland Britain. Forestry 2009, 82, 185-198.

86. Price, M.; Price, C. Creaming the best or creatively transforming? Might felling the biggest trees first be a win-win strategy? For. Ecol. Manag. 2006, 224, 297-303.

87. Price, C.; Price, M. Cost-benefit analysis of continuous cover forestry. Scand. Soc. For. Econ. 2008, 42, 36-65. 
88. Davies, O.; Kerr, G. The Costs and Revenues of Transformation to Continuous Cover Forestry: Modelling Silvicultural Options with Sitka Spruce, 2011; p. 63. Available online: http://www.forestry.gov.uk/pdf/Costs_and_Revenues_of_CCF_March_2011.pdf/\$file/Costs_and _Revenues_of_CCF_March_2011.pdf (accessed on 16 December 2014).

89. Schutz, J.P.; Pukkula, T.; Donoso, P.; von Gadow, K. Historical emergence and current application of CCF. In Continuous Cover Forestry; Pukkula, T.T., von Gadow, K., Eds.; Springer: Berlin, Germany, 2012; pp. 1-28.

90. Jactel, H.; Nicoll, B.C.; Branco, M.; Gonzalez-Olabarria, J.R.; Grodzki, W.; Langstrom, B.; Moreira, F.; Netherer, S.; Orazio, C.; Piou, D.; et al. The influences of forest stand management on biotic and abiotic risks of damage. Ann. For. Sci. 2009, 66, 18.

91. Vitkova, L.; Ni Dhubhain, A.; Upton, V. Forestry professionals' attitudes and beliefs in relation to and understanding of continuous cover forestry. Scott. For. 2014, 68, 17-25.

92. Hale, S.E.; Gardiner, B.A.; Peace, A.; Nicoll, B.C.; Taylor, P.; Pizzirani, S. Comparison and validation of three versions of a forest wind risk model. Environ. Modell. Softw. 2015, 68, $27-41$.

93. Slodicak, M.; Novak, J. Silvicultural measures to increase the mechanical stability of secondary Norway spruce stands before conversion. For. Ecol. Manag. 2006, 224, 252-257.

94. Albrecht, A.; Hanewinkel, M.; Bauhus, J.; Kohnle, U. How does silviculture affect storm damage in forests of south-western Germany? Results from empirical modelling based on long-term observations. Eur. J. For. Res. 2012, 131, 229-247.

95. Broome, A.; Hendy, S.; Peace, A. Annual and spatial variation in coning shown by the Forest Condition Monitoring programme data for Norway spruce, Sitka spruce and Scots pine in Britain. Forestry 2007, 80, 17-28.

96. Kerr, G.; Stokes, V.; Peace, A.; Wylder, B. Prediction of conifer natural regeneration in a “data-poor" environment. Scott. For. 2011, 65, 28-36.

97. Quine, C.P.; Malcolm, D.C. Wind driven gap development in Birkley Wood, a long-term retention of planted Sitka spruce in upland Britain. Can. J. For. Res. 2007, 37, 1787-1796.

98. Quine, C.P. A preliminary survey of regeneration of Sitka spruce in wind-formed gaps in British planted forests. For. Ecol. Manag. 2001, 151, 37-42.

99. Hanewinkel, M.; Frutig, F.; Lemm, R. Economic performance of uneven-aged forests analysed with annuities. Forestry 2014, 87, 49-60.

100. Puettmann, K.J.; Coates, K.D.; Messier, C. A Critique of Silviculture: Managing for Complexity; Island Press: Washington, DC, USA, 2009; p. 190.

101. Cameron, A.D. Building resilience into Sitka spruce (Picea sitchensis (Bong.) Carr.) forest in Scotland in response to the threat of climate change. Forests 2015, 6, 398-415.

102. Kerr, G.; Morgan, G.; Blyth, J.; Stokes, V. Transformation from even-aged plantations to an irregular forest: The world's longest running trial area at Glentress, Scotland. Forestry 2010, 83, 329-344.

103. Cameron, A.D.; Mason, W.L. Western hemlock: Are we ignoring one of our most useful tree species? Scott. For. 2013, 67, 10-14.

104. Mason, W.L. The role of true fir species in the silviculture of British forests: Past, present and future. Kastomonu University. J. For. Fac. 2012, 12,15-26. 
105. Nicoll, B.C.; Gardiner, B.A.; Rayner, B.; Peace, A.J. Anchorage of coniferous trees in relation to species, soil type, and rooting depth. Can. J. For. Res. 2006, 36, 1871-1883.

106. Deal, R.L.; Hennon, P.; O’Hanlon, R.; D’Amore, D. Lessons from native spruce forests in Alaska: Managing Sitka spruce plantations worldwide to benefit biodiversity and ecosystem services. Forestry 2014, 87, 193-208.

107. Bauhus, J.; Schmerbeck, J. Silvicultural options to enhance and use forest plantation biodiversity. In Ecosystem Goods and Services from Plantation Forests; Bauhus, J., van der Meer, P.J., Kanninen, M., Eds.; Earthscan: London, UK, 2010; pp. 96-139.

108. Ray, D.; Bathgate, S.; Moseley, D.; Taylor, P.; Nicoll, B.; Pizzirani, S.; Gardiner, B. Comparing the provision of ecosystem services in plantation forests under alternative climate change adaption management options in Wales. Reg. Environ. Chang. 2014, doi:10.1007/s10113-014-0644-6. Available online: http://link.springer.com/article/10.1007/s10113-014-0644-6 (accessed on 15 December 2014).

(C) 2015 by the authors; licensee MDPI, Basel, Switzerland. This article is an open access article distributed under the terms and conditions of the Creative Commons Attribution license (http://creativecommons.org/licenses/by/4.0/). 